\title{
Hydrological and Hydro-Meteorological Extremes and Related Risk and Uncertainty
}

\author{
Athanasios Loukas $^{1, *(\mathbb{D})}$, Luis Garrote ${ }^{2}(\mathbb{D})$ and Lampros Vasiliades ${ }^{3}(\mathbb{D}$ \\ 1 Department of Rural and Surveying Engineering, Aristotle University of Thessaloniki, \\ 54124 Thessaloniki, Greece \\ 2 Department of Civil Engineering, Hydraulics, Energy and Environment, Universidad Politécnica de Madrid, \\ 28040 Madrid, Spain; 1.garrote@upm.es \\ 3 Department of Civil Engineering, School of Engineering, University of Thessaly, 38221 Volos, Greece; \\ lvassil@civ.uth.gr \\ * Correspondence: agloukas@topo.auth.gr; Tel.: +30-2310-996103
}

check for

updates

Citation: Loukas, A.; Garrote, L.; Vasiliades, L. Hydrological and Hydro-Meteorological Extremes and Related Risk and Uncertainty. Water 2021, 13, 377. https://doi.org/ $10.3390 /$ w13030377

Academic Editor: Marco Franchini

Received: 27 October 2020

Accepted: 27 January 2021

Published: 1 February 2021

Publisher's Note: MDPI stays neutral with regard to jurisdictional claims in published maps and institutional affiliations.

Copyright: (c) 2021 by the authors. Licensee MDPI, Basel, Switzerland. This article is an open access article distributed under the terms and conditions of the Creative Commons Attribution (CC BY) license (https:/ / creativecommons.org/licenses/by/ $4.0 /)$.
Natural hazards have caused significant damages to natural and manmade environments during the last few decades. Hydro-meteorological hazards are among the most destructive hazards and are considered responsible for the loss of human lives, infrastructure damages and economic losses [1]. Nowadays, there is a rising global awareness for hydrological hazard's impacts mitigation due to the increase in frequency, magnitude, and intensity of extreme events [2,3]. The occurrence of hydrological and hydro-meteorological extremes (i.e., storms, floods and hydrological droughts) has always been a threat to human society. The observed increase in weather and hydro-climatological extremes, particularly in the last decades, has brought much-needed attention to the subject [4]. For example, the annual average flood damage in Europe in the last few decades amounts to approximately $€ 4.0$ billion per year, and in the period 1998-2004, Europe experienced more than 100 major hydrological extremes resulting in some 700 fatalities [5]. Using the International Disaster-Emergency Events Database (EM-DAT) that contains core data on the occurrence and effects of more than 24,000 natural and technological disasters from 1900 to the present day, for the last 10 years (2009-2018), 343 natural disasters per year were recorded in the EM-DAT with on average over 45,000 deaths, 185 million people affected and US $\$ 176$ billion in economic losses across the world. For the year 2019, floods were the deadliest type of disaster, accounting for $43.5 \%$ of deaths, followed by extreme temperatures at $25 \%$ (mainly due to heatwaves in Europe) and storms at 21.5\%. However, storms affected the highest number of people, accounting for $35 \%$ of the total affected, followed by floods with $33 \%$ and droughts with $31 \%$ [6].

This WATER Special Issue (S.I.) titled "Hydrological and Hydro-Meteorological Extremes and Related Risk and Uncertainty" collects and includes selected papers presented in the 3rd International Electronic Conference on Water Sciences (ECWS-3) held from 15 November 2018 to 30 November 2018. The objective of this Special Issue is to provide a forum for original articles related to the analysis and modeling of hydrological and hydro-meteorological extremes. The 10 papers of this Special Issue cover a wide range of research topics related to hydrological and hydro-meteorological extremes and related risk and uncertainty, including issues of climate change impacts and structure design.

Sordo-Ward et al. [7] evaluated various management alternatives and adaption measures to enhance potential water availability for agriculture under climate change scenarios, considering only two water uses, irrigation and urban water supply. The management goal is to maximize potential water availability using various measures. A methodology was developed using the water availability and adaptation policy analysis (WAAPA) model and applied in five (5) representative regulated international transboundary river basins of southern Europe, namely, Duero-Douro, Ebro, Po, Maritsa-Evros, and Struma-Strymon and Guadalquivir River basin. Climate change impacts on runoff were evaluated using 
the outcomes of 16 ensembles of 5 global climate models (GCMs) with 11 regional climate models (RCMs) for the historical period 1960-1990 and 35 ensembles of 5 GCMS and 15 RCMs for the future period 2070-2100 for SRES scenarios, A2, B2, A1B and representative concentration pathways (RCPs), 2.6, 4.5, 6.0, 8.5. The results indicate that most climate change scenarios result in the reduction of mean annual flow for the six study river basins, and the results are bound with large uncertainties in the estimation of future mean annual flow and potential water availability due to the wide range of emissions scenarios analyzed and the use of various climate models. The results also indicate that, in some river basins, such as Ebro and Struma-Strymon River basins, the adoption of management measures can significantly increase water availability and partly compensate the future water scarcity, whereas, in other river basins, such as Guadalquivir, this is not possible.

Molina et al. [8] present a methodological framework to study non-stationarity of hydrological patterns in time-series. The temporal alteration of traditional hydrological patterns is being observed worldwide, leading to higher variability and unpredictable extreme events, such as floods and droughts. This change is largely due to climate change producing a growing uncertainty in hydrological variables, especially river runoff. The proposed framework is based on causality, a stochastic approach to extract the hidden logical time-dependency structure that inherently underlies into hydrological series, and it, ultimately, includes a predictive method for the runoff temporal behavior. The proposed methodology has been applied to an unregulated stretch, the Mijares River basin (Jucar River basin, Spain), with a very high time-dependency behavior. The application results indicate that substantial economic/environmental savings may be gained in the reservoir design, and it may help to the more sustainable management of river basins through more reliable control reservoirs' operation.

Näschen et al. [9] present an analysis of climate change impacts on the hydrology of an East African watershed, the Kilombero watershed, subbasin of Rufiji basin in Tanzania. The climate change impacts until 2060 have been assessed using a regional climate model ensemble of the Coordinated Regional Downscaling EXperiment (CORDEX) Africa project. The outputs of six ensembles of GCMs and RCMs have been downscaled and used for two RCPs scenarios (e.g., RCP4.5 and RCP8.5). The semi-distributed Soil and Water Assessment Tool (SWAT) hydrological model has been calibrated and used to analyze the climate change impacts on the hydrological processes of the study watershed. The results indicate that climate change will have significant impacts on the hydrology of the study watershed, specifically in seasonal temperature, annual precipitation, water yield and surface runoff and the frequency and magnitude of peak and low flows. Finally, the time of peak flows is likely to shift from April to May from the 2020s onwards.

The study of Bonzi et al. [10] investigates the connection between surface water and groundwater for rainfall-runoff modeling at the Alcantara River basin in the Sicily region of Italy. A diverse flow regime is observed at the study area where the upstream flow is intermittent, and its middle valley is characterized by perennial surface flows, enriched by spring water arising from the big aquifer of the northern sector of the Etna volcano. The aquifer-river interaction processes are modeled using a simple, spatially lumped rainfallrunoff model (IHACRES model) that is modified with a simple groundwater model to represent the groundwater interaction. The modified version of the IHACRES model is calibrated and validated for the periods 1980-1984 and 1986-1988, respectively, at one of the main cross-sections of the Alcantara river basin, namely Moio Alcantara, where daily streamflow data are available for both model calibration and simulation. A first-order analysis is also performed to assess the sensitivity of model parameters. The results show improvements in model performance with respect to the original version of the IHACRES model [11]. In particular, the modified model appears capable to better simulate not only the flood peaks but also the recession curves describing the groundwater aquifer contribution at the end of the wet seasons, and it may be generalized after extensive testing.

The study of Ponomarev et al. [12] demonstrates the dependence between forest burning rates and an abnormal decrease in Siberian river discharges under the climatic 
conditions of the permafrost zone in selected regions of Central Siberia and Eastern Siberia/Yakutia. The following aspects are considered and analyzed: (i) the long-term river discharge dynamics and anomalies; (ii) the correlation of long-term data on discharge minima and the relative burned area (RBA); and (iii) the intra-seasonal variations of the post-fire river discharge. Four rivers are selected to examine the dependence between forest burning rates and runoff: the Lower Tunguska and the Podkamennaya Tunguska rivers of the Yenisey River basin and the Aldan and Viluy rivers of the Lena River basin. All watersheds are forest-dominated and susceptible to fire with different groundwater mechanisms, which are limited by the continuous permafrost and soil conditions. The long-term and seasonal variations of river discharge for the period 1939-2015 (based on The Global Runoff Data Center database) together with the forest burning dynamics within the river basins for the period 1996-2015 (adopted from the Sukachev Institute of Forest database) are analyzed and compared. The analysis of available chronologies of extreme fire events and relative burned areas (RBAs) showed a high correlation with intra-seasonal data on the runoff minima. The most significant response of river discharges to the wildfire effect is shown for the late summer/autumn season after extreme wildfires during the summer period. Late summer and autumn anomalies of discharge are typical for the rivers of Central Siberia during seasons of extreme forest burning based on the correlation analysis. However, this correlation is lower for the rivers of Eastern Siberia/Yakutia. It could be assumed that the local post-fire permafrost soil conditions can explain the revealed differences in the runoff in Siberia.

Vantas et al. [13] present a methodology for studying rainfall erosivity density in Greece for soil erosion studies under climate change conditions. Since the most significant process responsible for soil loss is related to rainfall intensity, any possible increase of future rainfall intensity will directly affect soil erosion rates and intensify desertification mechanisms. Thus, the first part of this study evaluates the impact of the ratio of the missing values on the computation of the rainfall erosivity factor, $R$, and erosivity density, $E D$. The second part investigates the temporal trends and defines homogeneous regions using an unsupervised classification method with a similar monthly distribution of $E D$ and taking into account the presence of missing values in precipitation records. Preprocessed and free from noise and errors, rainfall data from 108 stations across Greece are extracted from the Greek National Bank of Hydrological and Meteorological Information using the "hydroscoper" R-interface package [14]. Monte Carlo simulation results show that $E D$ is more robust against the presence of missing precipitation values than the rainfall erosivity $R$ factor. Hence, $E D$ should be preferred for the assessment of erosivity with incomplete datasets in Greece over the direct computation of $R$ because it does not introduce systematic errors due to the missing data. Furthermore, the stationarity of annual values of ED is found for the majority of the stations that share a time length of 30 years, in contrast to the reported precipitation and rainfall intensity trends for the same time period in Greece. Finally, cluster analysis of monthly ED values revealed three homogeneous regions in Greece with different seasonal distributions of intense and erosive rainfalls. The identified rainfall distribution patterns could also be used to estimate $R$ values in Greece, using precipitation data with coarser resolutions.

Lazoglou et al. [15] present a methodology for bias correction of the regional climate model of the Max Plank Institute (MPI model) using copulas for hydrological studies (rainfall-runoff modeling with limited data) due to climate change scenarios. Furthermore, the lack of hydro-meteorological data in various areas greatly hinders the successful application of rainfall-runoff models in climate change studies. Hence, data from general circulation models (GCMs) and/or regional climate models (RCMs) could be used as an alternative in the rainfall-runoff process. However, these data often present biases compared to the observed data and consequently, several methods have been developed for correcting statistical biases and to use them efficiently in climate change studies. The present study tests 15 copula families (Gaussian, Student's t, Clayton Gumbel, Frank, Joe, BB1, BB6, BB7, BB8 and their rotated versions) and used for modeling the dependence 
between the daily mean and total monthly precipitation using E-OBS data [16] in the transboundary Mesta/Nestos river basin in order to use this relationship for the bias correction of the MPI climate model monthly precipitation for the period 1981-2000. Apart from the copula family selection, the marginal distributions of the E-OBS monthly totals are also estimated using the normal, lognormal, gamma, GEV and Pareto distributions. Finally, the three different datasets (i.e., E-OBS, MPI and bias-corrected MPI precipitations) are used as inputs to the spatially distributed MODelisation du SURface (MODSUR) [17] hydrological model for discharge modeling at the study area. The parameterization of the MODSUR model was based on a previous application of the model at the same study area and is based on a grid formulation modeling scheme with 9212 grid cells [18]. The results show that the MPI model significantly overestimates the E-OBS data while the differences are reduced sufficiently after the bias correction method. The Student-t family was selected to model the dependence between daily mean and total monthly precipitation since it was ranked 1st among the 15 study copulas for more than half grids $(60 \%)$ of the Nestos region. The Weibull distribution was selected to model the marginal distribution in the majority of grid points (87\%), while in the rest grid points, the gamma distribution was used. A comparison of the bias-corrected precipitation (with the final selected copula method) with the bias-corrected precipitation derived from three widely used methods (delta, scaling and empirical quantile mapping) was conducted and showed that the biascorrected precipitations with the copula method are closer to the E-OBS data compared with the other three methods. Finally, the application of the hydrological model with the three different datasets verified the results of the precipitation analysis and show that simulated discharges in the case of copula bias-corrected data present an increased correlation with the observed flows, which are comparable with the E-OBS dataset.

Lee et al. [19] describe a technique to build a rainfall ensemble by adding a perturbation field to radar rainfall data. The perturbation is based on the observation errors between ground and radar data and is conditioned to reflect the spatial and temporal structure of rainfall. The rainfall ensemble is processed through three well-known rainfall-runoff models: the Tank model, the SSARR model and the storage function model. The results from the three models were integrated using three blending techniques: the multimodel super ensemble, the simple model average and the mean squared error. In their analysis of results for the case study of the Jungrang Basin in South Korea, the authors verified that the integrated runoff curve produced by the multimodel super ensemble showed the best result. This contribution illustrates how rainfall uncertainty can be described through an ensemble and how blending techniques can be applied to reduce runoff uncertainty.

The last two papers deal with the assessment of the performance of hydraulic structures exposed to hydro-meteorological extremes. Gabriel-Martin et al. [20] discuss the influence of the initial reservoir level on the evaluation of hydrological dam safety. During the design stage, it is customarily assumed that the reservoir is full when the design flood arrives. This assumption is reasonable because dam operation during its life span may change from the originally intended conditions. However, the authors argue that the initial reservoir level is, in fact, a random variable and should be accounted for while performing risk assessment while the dam is in the operation stage. They propose and implement a methodology to assess the influence of the initial reservoir level in hydrological risk analysis. Their method is based on the generation of an ensemble of forcing hydrographs through Monte Carlo simulation and the simulation of dam operation starting from different reservoir levels. They compare three scenarios, with the initial reservoir level equal to the maximum normal level, equal to the maximum conservation level and sampled from the probability distribution derived from historical records and apply a global economic risk index, based on the probability distributions of maximum water level in the reservoir and maximum spilled discharge. Their approach was successfully tested in a gated-spillway dam located in Spain. Their results show that the probability distribution of initial reservoir level may indeed change the outcome of dam risk assessment and should therefore be included in the analysis. 
The paper by Rebollo et al. [21] deals with the design of energy dissipation structures, which are important components of flood risk management schemes. It is focused on the analysis of the role played by aeration in energy dissipation structures. They address this problem through an experimental setup, where they characterize the effect of aeration on boundary friction in supercritical and fully turbulent flows. They produced aerated flows with different air concentrations and accelerated them through a spillway chute to analyze the velocity profile and air concentration of the flow at the entrance of the stilling basin. They estimated Manning's roughness coefficient for different aeration rates. Their experimental results showed that aeration reduced the rigid-boundary friction, and this effect generates flow acceleration. They developed an original formulation to predict the change in Manning's roughness coefficient as a function of air concentration, which may be useful to design more efficient energy dissipation structures.

In conclusion, this Special Issue contains 10 studies with important results, covering several aspects of hydrological extremes and related risk and uncertainty. Advanced models and methodologies were developed for the analysis, simulation, forecasting, and hazard prevention of weather-induced extreme hydrological events and the assessment of disaster risk. Assessing the risk and uncertainty of hydrological and hydro-meteorological extremes is a crucial step towards decision-making.

Author Contributions: Conceived the structure and wrote the manuscript, A.L., L.G. and L.V. All authors have read and agreed to the published version of the manuscript.

Funding: This research received no external funding.

Acknowledgments: The guest editors thank all the authors of the published papers, manuscript reviewers, assistant editors and publication team of MDPI for the great support to the realization of the present Special Issue.

Conflicts of Interest: The authors declare no conflict of interest.

\section{References}

1. Tsakiris, G. Flood risk assessment: Concepts, modelling, applications. Nat. Hazards Earth Syst. Sci. 2014, 14, 1361-1369. [CrossRef]

2. Hall, J.; Arheimer, B.; Borga, M.; Brázdil, R.; Claps, P.; Kiss, A.; Kjeldsen, T.R.; Kriaučiūnienė, J.; Kundzewicz, Z.W.; Lang, M.; et al. Understanding flood regime changes in Europe: A state-of-the-art assessment. Hydrol. Earth Syst. Sci. 2014, 18, 2735-2772. [CrossRef]

3. Kreibich, H.; Di Baldassarre, G.; Vorogushyn, S.; Aerts, J.C.J.H.; Apel, H.; Aronica, G.T.; Arnbjerg-Nielsen, K.; Bouwer, L.M.; Bubeck, P.; Caloiero, T.; et al. Adaptation to flood risk: Results of international paired flood event studies. Earth's Future 2017, 5, 953-965. [CrossRef]

4. Blöschl, G.; Hall, J.; Viglione, A.; Perdigão, R.A.P.; Parajka, J.; Merz, B.; Lun, D.; Arheimer, B.; Aronica, G.T.; Bilibashi, A.; et al. Changing climate both increases and decreases European river floods. Nature 2019, 573, 108-111. [CrossRef] [PubMed]

5. AghaKouchak, A.; Easterling, D.; Hsu, K.; Schubert, S.; Sorooshian, S. Extremes in a Changing Climate; Water Science and Technology Library; Springer: Dordrecht, The Netherlands, 2013; Volume 65, ISBN 978-94-007-4478-3.

6. CRED (Centre for Research on the Epidemiology of Disasters). Natural Disasters 2019; CRED: Brussels, Belgium, 2020. Available online: https:/ / emdat.be/sites/default/files/adsr_2019.pdf (accessed on 24 October 2020).

7. Sordo-Ward, A.; Granados, A.; Iglesias, A.; Garrote, L.; Bejarano, M. Adaptation Effort and Performance of Water Management Strategies to Face Climate Change Impacts in Six Representative Basins of Southern Europe. Water 2019, 11, 1078. [CrossRef]

8. Molina, J.-L.; Zazo, S.; Martín, A.-M. Causal Reasoning: Towards Dynamic Predictive Models for Runoff Temporal Behavior of High Dependence Rivers. Water 2019, 11, 877. [CrossRef]

9. Näschen, K.; Diekkrüger, B.; Leemhuis, C.; Seregina, L.; van der Linden, R. Impact of Climate Change on Water Resources in the Kilombero Catchment in Tanzania. Water 2019, 11, 859. [CrossRef]

10. Borzì, I.; Bonaccorso, B.; Fiori, A. A Modified IHACRES Rainfall-Runoff Model for Predicting the Hydrologic Response of a River Basin Connected with a Deep Groundwater Aquifer. Water 2019, 11, 2031. [CrossRef]

11. Jakeman, A.J.; Hornberger, G.M. How much complexity is warranted in a rainfall-runoff model? Water Resour. Res. 1993, 29, 2637-2649. [CrossRef]

12. Ponomarev, E.I.; Ponomareva, T.V.; Prokushkin, A.S. Intraseasonal Dynamics of River Discharge and Burned Forest Areas in Siberia. Water 2019, 11, 1146. [CrossRef]

13. Vantas, K.; Sidiropoulos, E.; Loukas, A. Robustness Spatiotemporal Clustering and Trend Detection of Rainfall Erosivity Density in Greece. Water 2019, 11, 1050. [CrossRef] 
14. Vantas, K. hydroscoper: R interface to the Greek National Data Bank for Hydrological and Meteorological Information. J. Open Source Softw. 2018, 3, 625. [CrossRef]

15. Lazoglou, G.; Anagnostopoulou, C.; Skoulikaris, C.; Tolika, K. Bias Correction of Climate Model's Precipitation Using the Copula Method and Its Application in River Basin Simulation. Water 2019, 11, 600. [CrossRef]

16. Haylock, M.R.; Hofstra, N.; Tank, A.M.G.K.; Klok, E.J.; Jones, P.D.; New, M. A European daily high-resolution gridded data set of surface temperature and precipitation for 1950-2006. J. Geophys. Res. 2008, 113, D20119. [CrossRef]

17. Ledoux, E.; Girard, G.; de Marsily, G.; Villeneuve, J.P.; Deschenes, J. Spatially Distributed Modeling: Conceptual Approach, Coupling Surface Water and Groundwater. In Unsaturated Flow in Hydrologic Modeling: Theory and Practice; Morel-Seytoux, H.J., Ed.; NATO ASI Series; Springer: Dordrecht, The Netherlands, 1989; pp. 435-454. ISBN 978-94-009-2352-2.

18. Skoulikaris, C.; Ganoulis, J. Climate Change Impacts on River Catchment Hydrology Using Dynamic Downscaling of Global Climate Models. In National Security and Human Health Implications of Climate Change; Fernando, H.J.S., Klaić, Z., McCulley, J.L., Eds.; Springer: Dordrecht, The Netherlands, 2012; pp. 281-287.

19. Lee, M.; Kang, N.; Joo, H.; Kim, H.S.; Kim, S.; Lee, J. Hydrological Modeling Approach Using Radar-Rainfall Ensemble and Multi-Runoff-Model Blending Technique. Water 2019, 11, 850. [CrossRef]

20. Gabriel-Martin, I.; Sordo-Ward, A.; Garrote, L.; Granados, I. Hydrological Risk Analysis of Dams: The Influence of Initial Reservoir Level Conditions. Water 2019, 11, 461. [CrossRef]

21. Rebollo, J.; López, D.; Garrote, L.; Ramos, T.; Díaz, R.; Herrero, R. Experimental Analysis of the Influence of Aeration in the Energy Dissipation of Supercritical Channel Flows. Water 2019, 11, 576. [CrossRef] 